ISSN No. 0974-035X

An indexed refereed \& peer-reviewed journal of higher education

Towards Excellence

UGC-HUMAN RESOURCE DEVELOPMENT CENTRE

Gujarat University, Ahmedabad-380009, Gujarat, India

\title{
ANALYSIS OF MOB LYNCHING AND RELIGIOUS RIGHTS IN INDIA
}

\section{Ms. Ashima Jain}

\begin{abstract}
Freedom of Religion guaranteed under the Indian Constitution from Article 25-30. The concept of Secularism is implicit in Preamble which secures to its citizen's liberty of thought, expression, faith and worship. And then after 42 amendment1976, the word secular was specifically being added in the constitution. The article digs deeper into recent developments in the matter of religious faiths and what judiciary has interpreted to maintain an egalitarian society. The judiciary issues guidelines and one such issue in which detailed guidelines have been issued is Mob Lynching. In this paper there is discussion on the concept of religious conflicts and reasons behind it and solutions to bring unity in the country.
\end{abstract}

\section{Keywords: Judiciary, Preamble, Conflict}

\section{INTRODUCTION}

Lynching as defined in Britannica means a form of violence where a mob, under cover of providing justice and that too without trial, executes an offender putting that person under huge torture and no due process of law is followed ${ }^{1}$

Religion means belief and worship of God and being done regularly. It is kind of specific fundamental beliefs. In India every religion plays an important role and is protected under Indian Constitution. In India there are different religions and every religion thinks itself as superior and others as inferior because of which there are seen clashes in the society. Secularism although has been a universal principle which preserves the spirit of integration among all religions yet 
Towards Excellence: An Indexed, Refereed \& Peer Reviewed Journal of Higher Education / Ms. Ashima Jain/ Page 36-40

communal disharmony is rampant ${ }^{2}$ It was observed that the cry over one's religion is in danger always stifles emotions which are violent and brings extreme situations in society ${ }^{3}$

In Vasudev v. Vamanji ,it was laid that the state protects all religion and interferes none. There are various laws to regulate religious riots such as The Religious Institutions (Prevention of Misuse) Act,1988 under which under Article3, it has been prescribed that no religious place is to be used for any political activity. ${ }^{4}$

\section{ANALYSIS}

These extrajudicial killings under the garb of reasoning to protect law are altering the constitutional order. The court had time again laid preventive, punitive and remedial measures such as to not to allow the mob to gather at one place for such activities and to disperse them under section 129 Criminal Procedure Code $1973^{5}$

And other being provision of free legal aid to victims suffered due to such violence. An expeditious trial for the culprits of mob lynching is required to be done. Such horrendous acts should not be allowed by the State as these being laid down under Tehseen S. Ponnalwala v. Union of India and ors. ${ }^{6}$ Some other in the combine are:

A) Broadcasting by Central and State Governments on television about the consequences of mob lynching.

B) Whoever incites mob violence his case has to be registered under Section 153 An Indian Penal Code 1860.

C) The victim should be given compensation under Section 357 A of Criminal Procedure Code 1973

D) Fast Track Courts need to adjudicate mob Lynching cases.

Apart from this time and again court reiterated in Nandini Sundar and Ors. The V. State of Chhattisgarh, ${ }^{7}$ that no one should take the law in their own hands or become the guardian of law 
Towards Excellence: An Indexed, Refereed \& Peer Reviewed Journal of Higher Education / Ms. Ashima Jain/ Page 36-40

as this duty is total of States. Fraternity is required to be promoted and untoward incidents to be avoided.

In an article, it was analyzed by an author that timely response from the civil society to such issues of mob violence has to be resorted ${ }^{8}$

This mob lynching is causing more and more religious violence and hence the guidelines issued by the Supreme Court in State of Karnataka v. Dr Praveen Bhai Togadia ${ }^{9}$ is required to be adhered upon. Anything said which hampers communal harmony is against constitutional values. The ideal situation is Unity in Diversity and unites people from different cultures, ethos and values. The nation progresses when the basic features such as secularism, socialism and fraternity etc. are upheld.

Even we look at whether such groups are constitutional or not, the answer is one that such kinds of mob lynching are unconstitutional. As under section 34 or 149 read with Section 302, criminal liability is created on them who are killing someone with intention of murder. Several other punishments are prescribed under the Code of Criminal Procedure which is imposed under acts which take someone's life to be it an attempt or an incitement. ${ }^{10}$

Yet another noting which was done by the Supreme Court in U.P. Shaskiya Adhivakta Kalyan Samiti v. the State of U. $\mathrm{P}^{11}$, that increasing in public lynching and agitations, are due to inaction which is not taken by higher authorities against the offenders. A quotation was also quoted in this case as

\section{"My Grievous tale to you is but a story;}

\section{The Stars Weep tears of blood to hear its told."}

There are judicial precedents which embark upon the necessity of a society under which there is a requirement to have a stable and peaceful environment to live for the people with brotherhood. In Pannalal Bansilal and ors. V State of A.P and Anr., the court held that in a pluralistic society like India where different religions coexist the founding fathers were confronted with problems to unify and integrate people of different faiths and provide an integrated secular nation. Although the 
Towards Excellence: An Indexed, Refereed \& Peer Reviewed Journal of Higher Education / Ms. Ashima Jain/ Page 36-40

directive principles provide to foster uniformity among different faiths. A uniform law is required but enactment in one go would create issues and may be counterproductive. Instead, the mischief or defect which is most acute can be remedied through stages and not in one go. ${ }^{12}$

Various news have also covered the horrendous acts of mob violence which overthrow the law of country by doing such acts. ${ }^{13}$ Various reports also indeed has come out after various incidents of mob lynching in India. ${ }^{14}$ False messages are also circulated and hence to prevent them wats app has also limited forwarding of messages. ${ }^{15}$

\section{CONLCUSION}

What is required from every place is teaching lessons, conducting seminars, workshops to vigilantism every citizen of India to stop such acts of mob lynching. These self-styled courts who give punishment to anyone are required to be stopped. Media also has special role to play as proper news and correct views are required to be shown and unnecessary acts have to be avoided to be shown so that public at large do not get incited to news. What is required is from every citizen of India to imbibe the feeling of brotherhood amongst each other and promote excellence of our country through spirit of oneness. Our constitution has already bestowed us with such innumerable fundamental rights to enjoy which also includes freedom of religion, to administer institutions, no discrimination. Acts of violence has to be avoided. Solutions like:

i) Call for a response from all Governments.

ii) Catalyzing changes in law.

iii) Devising benchmarks and development of human rights approach that comports with the development of Rights. 
Towards Excellence: An Indexed, Refereed \& Peer Reviewed Journal of Higher Education / Ms. Ashima Jain/ Page 36-40

1 https://www.britannica.com/topic/lynching, last accessed on 01/01/2020

2 Dr. Bhagyashree A. Deshpande, Law and Social Transformation in India,2018, pg. 2

3 P. Ishwar Bhat, Law and Social Transformation, 1st Ed. 2009, Rep 2012, Eastern Bok Company, Lucknow at p. 229

4 Vasudev v. Vamanji, ILR 1881 Bom. 80

5 Section 129 Criminal Procedure Code, 1973, Dispersal of assembly by use of civil force.

6 Tehseen S.Ponnalwala v. Union of India and ors. AIR 2018 SC3354

7 Nandini Sundar and Ors. V. State of Chhattisgarh (2011)7 SCC 547

8 N. Dutta. "Rise in Street Violence: Slide into Mob Rule?" Economic and Political Weekly, vol. 35, no. 8/9, 2000, pp. 604-605. JSTOR, Accessed 22 Jan. 2021.

9 State of Karnataka v. Dr. Praveen Bhai Togadia (2004) 4 SCC 684

10 Anubhav Vashishtha and Abhay Pachauria, 5 August 2020)

https://www.outlookindia.com/website/story/opinion-mob-lynching-a-crime-that-exonerates-theoffenders-in-india/358031, last accessed on 01/01/2020

11 U.P. Shaskiya Adhivakta Kalyan Samiti v. State of U.P. 2012(5) ADJ 271

12 (1996) 1 SCR 603

13 SC seeks response from rajasthan government on mob lynching [india]. (2018, Aug 21). The Times of India last accessed on https://timesofindia.indiatimes.com/india/sc-seeks-responsefrom-rajasthan-government-on-mob-lynching/articleshow/65469745.cms

14 JANHASTAKSHEP. "Mob Lynching in Dadri: A Report.” Economic and Political Weekly, vol. 50, no. 42, 2015, pp. 83-87., Accessed 18 Feb. 2021.

15 WhatsApp to restrict message forwarding after India mob lynching's., (2018, Jul 20), https://www.theguardian.com/technology/2018/jul/20/whatsapp-to-limit-message-forwardingafter-india-mob-lynchings, last accessed on 18/02/2021

Ms. Ashima Jain

PhD Research Scholar, Department of Law, University of Rajasthan, Jaipur, Email id-ashima.jain08@gmail.com 